Trinity University

Digital Commons @ Trinity

Art and Art History Faculty Research

Art and Art History Department

9-20-2012

\title{
Intention and Interpretation in Hans Namuth's Film, Jackson Pollock
}

Michael Schreyach

mschreya@trinity.edu

Follow this and additional works at: https://digitalcommons.trinity.edu/art_faculty

Part of the History of Art, Architecture, and Archaeology Commons

\section{Repository Citation}

Schreyach, M. (2012). Intention and Interpretation in Hans Namuth's Film, Jackson Pollock. Forum for Modern Language Studies, 48(4), 437-452.

This Article is brought to you for free and open access by the Art and Art History Department at Digital Commons @ Trinity. It has been accepted for inclusion in Art and Art History Faculty Research by an authorized administrator of Digital Commons @ Trinity. For more information, please contact jcostanz@trinity.edu. 

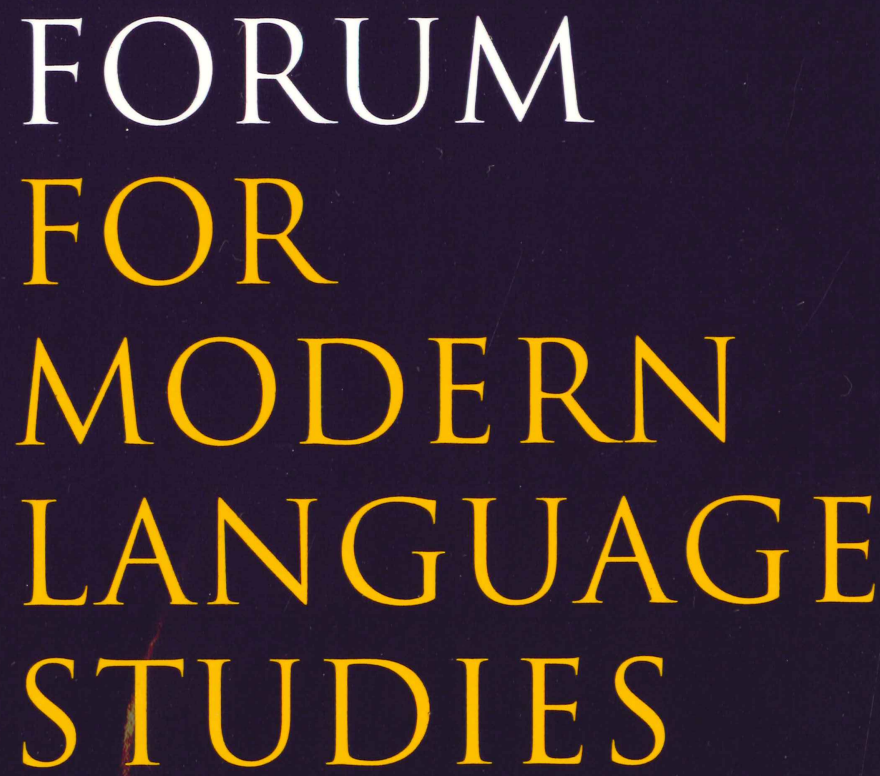

THE JOURNAL OF LITERARY, CULTURAL AND LINGUISTIC STUDIES FROM THE MIDDLE AGES TO THE PRESENT

VOLUME 48 NUMBER 4 OCTOBER 2012

\section{SPECIAL ISSUE}

Artists' Statements: Origins, Intentions, Exegesis

EDITED BY NATALIE ADAMSON AND LINDA GODDARD 


\section{CONTENTS}

Introduction - Artists' Statements: Origins, Intentions, Exegesis

Natalie Adamson and Linda Goddard

Art in German: Artistic Statements by

Albrecht Dürer

Jeffrey Ashcroft

'Her Painting of Apricots': The Invisibility of

Mary Beale (1633-1699)

Helen Draper

Ernst Ludwig Kirchner as his Own Critic: The Artist's Statements as Stratagems of Self-Promotion Christian Weikop

Artists' Statements at Work: Visual Artists and the Julius Rosenwald Fund

Lindsay J. Twa

Intention and Interpretation in Hans Namuth's

Film, Jackson Pollock

Michael Schreyach

The Artist as a Work-in-Progress: General Idea and the Construction of Collective Identity Deborah Barkun

Černý's Counterfeit Collaborators

Preston McLane

Notes on the Contributors

Reviews 


\title{
INTENTION AND INTERPRETATION IN HANS NAMUTH'S FILM, JACKSON POLLOCK
}

\author{
MICHAEL SCHREYACH
}

\begin{abstract}
Because many of Jackson Pollock's most familiar statements are multiply authored, they seem to challenge basic assumptions regarding the transparency of intention to meaning that they are often presumed to enunciate. The fact that Pollock's public declarations about his work are collages, juxtaposing different voices and points of view with his own, complicates our assessment of their validity as univocal expressions of his intentions. In his film fackson Pollock, Namuth utilizes those statements, many of which concern aspects of Pollock's technical procedure, as part of his strategy to ground the meaning of Pollock's paintings in the process by which his paintings were made. In this essay, I analyse Namuth's film as an instance of an anti-intentionalist, causal account of Pollock's work. I also point out what I take to be a detrimental consequence of the reduction of meaning to causes in a discussion of Rosalind Krauss's work on Namuth's photographs; namely, the conversion of the artwork into a 'text' or intentionless object. Additionally, I define the intentionalist position, staking out my view in relation not only to some recent theoretical work concerning intention and meaning, but also to the literary criticism of some of Pollock's contemporaries (the New Critics). Finally, I offer an interpretation of Pollock's Number I, 1949 that proceeds from the intentionalist position.

Keywords: Pollock, Jackson; Namuth, Hans; intention; interpretation; Number I, 1949; index; abstract expressionism; perception; Krauss, Rosalind
\end{abstract}

He talks with difficulty, searching painfully, almost agonizingly, for the right word, with constant apologies for not being 'verbal'. (Seldon Rodman on Jackson Pollock, I 956) ${ }^{1}$

Technique is just a means of arriving at a statement. (Jackson Pollock, I950) ${ }^{2}$

When in i95 I Jackson Pollock heard his voice-over for the eleven-minute film Hans Namuth had made about the artist played back, he hated it. ${ }^{3}$ Perhaps he sounded to himself as he sounds to listeners today: awkwardly unsure; hesitant and tentative; straining for expression, yet so reticent to speak 
that he delivers his words in a wooden monotone. The recorded vocal performance fails to convey a sense of Pollock's familiarity with the ideas he tries to express, and instead yields only splinters of biographical, aesthetic and technical information. Moreover, the bulk of his narration contains key words, phrases and sometimes whole sentences quoted from three previously published sources. In turn, many of these comments were not, or not primarily, self-generated, but garnered from friends, critics and his wife, Lee Krasner. ${ }^{4}$ Pollock begins his verbal statement by repeating, nearly exactly, biographical details about his training under Thomas Hart Benton which appeared in a I944 questionnaire for Arts and Architecture. ${ }^{5}$ Most of the remaining remarks come from a statement published in the only issue of Possibilities, a magazine edited by Barnett Newman and Robert Motherwell in the winter of $1947^{-48}$, and from an interview with William Wright in I950, broadcast by radio in $195^{1} .^{6}$ Parts of the later interview duplicate the earlier statement, so that when Pollock reuses them in the film, he triplicates. Additional words and phrases can be tracked to Pollock's undated, handwritten statements, and even to a New Yorker review that appeared in the summer of $195{ }^{\circ} .^{7}$ Namuth, glossing over the contest of egos famously drawn out by the process of filming, recounts: 'The text [of the script] was a communal effort. The three of us [including Paul Falkenberg, the film's producer] took bits and pieces from Jackson's writings and interviews and put them together.' 8

Pollock's well-known discomfort in explaining himself and his work provides a productive starting point for investigating certain problems involving 'artists' statements'. Of particular concern is determining how statements made by an artist about his or her working process, or even about the putative meaning of the resulting artworks, relate to intention. Art historians Fred Orton and Griselda Pollock suggest that, conventionally, art historians treat artists' statements as documentary evidence of their intentions and use them to reveal what an artwork means. In their view, however, this method sidesteps critical interpretation, and as a correction they call for an approach that 'remind[s] [us] of the gap between the art an artist makes and what he or she says about that art'. 9 The explanations provided by statements are 'not necessarily the meanings that [are] effected by [...] picture[s]'. ${ }^{10}$ Instead, statements are embedded in forms of political and cultural life which are the necessary grounding for any utterance, as well as any interpretation. Orton and Pollock thus question the often presumed transparency between artists' statements and the meaning of artworks, emphasizing instead the social-historical contexts within which meaning is constructed and intention is formed.

Jackson Pollock's statements challenge basic assumptions regarding the transparency of intention to meaning that they are often presumed to enunciate. The fact that his few public declarations about his work are collages, juxtaposing different voices and points of view with his own, complicates our assessment of their validity as univocal expressions of his intentions. Indeed, they might even call into question the status of intention as privately owned mental content 
available to an individual's solipsistic reflection. Against such doubt, Falkenberg, the experienced filmmaker who mentored Namuth during the production of the film, emphatically defended the validity of this kind of private ownership and introspection, claiming univocality for Pollock's narration:

We felt that this film was Jackson's and that if any voice were to accompany the picture, it should be his. No critic, however competent and influential, was to tell an audience what to see [and think]. [...] Jackson's gestures and voice [would] remain 'authentic'. These were his very words, the way he felt them, and how he spoke them! ${ }^{11}$

Perhaps Falkenberg's insistence on Pollock's 'authenticity' resulted from his concern that the multiplicity of voices involved in the film's script might undercut the singularity ('his very words') that he nevertheless wanted to imagine for Pollock's genuine voice ('the way he felt them'). The tension apparent in Falkenberg's testimony motivates me to propose that Pollock's words should not in any usual sense be understood as 'evidence' of his personal intentions, conceived of as pre-existing ideas or mental plans that are tacitly expressed by words or artworks. $^{12}$

Reflecting on the heterogeneity of Pollock's statements encourages us to revise and broaden our usual concept of intention, which we often take to mean an individual's conscious plan, purpose or goal. Nothing precludes the idea that intention may be formed through some intersubjective or collaborative process, or that it may unconsciously animate an artist's practice. Indeed, intention as such is often recognized retrospectively. Yet as Orton and Pollock suggest, problems invariably emerge when an artist's statement is considered to 'reveal' the intention 'behind' a work. The danger is to treat intention as a special kind of cause, and meaning as an effect, resulting in a conflation of meaning with causes that W. K. Wimsatt and Monroe Beardsley called the 'intentional fallacy'. ${ }^{13}$ Such an approach assumes that to understand the meaning, we must discover the intention, usually by reading the artist's statements as evidence of what he or she intended. Intention thus appears as something independent of, and temporally prior to, its realization in the artwork, and meaning becomes divided from it. But if we maintain the absolute identity of meaning and intention, as I propose we should, then it is unnecessary to think of artist's statements as revealing intention, as if they provide evidence of some cause that putatively precedes the meaning an artwork is claimed to have. At the risk of some preliminary confusion, I will call the position I advocate intentionalist, by which I mean to designate a newly conceptualized understanding of intention.

In this essay, I analyse Namuth's film as an instance of an anti-intentionalist, causal account of Pollock. Namuth does not interpret the meaning of Pollock's paintings, but rather identifies the meaning of his paintings with how they were made. This point of view is shared by some of the artist's earlier critics such as Harold Rosenberg and Allan Kaprow, and extends through the work of more recent commentators such as Amelia Jones and Jonathan Katz. ${ }^{14}$ I also point out what I take to be a detrimental consequence of the reduction of meaning to 
causes in a discussion of Rosalind Krauss's work on Namuth's photographs of Pollock; namely, the conversion of the artwork into a 'text' or intentionless object. Finally, I define an intentionalist position, in relation to some recent theoretical work concerning intention and meaning, and also consider the literary criticism of some of Pollock's contemporaries (the New Critics). Indeed, I rely on the artist's own statements to help make the position I advocate clearer and in turn offer an interpretation of Pollock's Number I, I949 that proceeds from the intentionalist position.

\section{Namuth's film as a causal account}

Namuth filmed Pollock in part because he was dissatisfied with dozens of still photographs he had taken of the painter in the summer of I950, which in his view did not sufficiently convey Pollock's 'continuous movement'. ${ }^{15}$ So viewers would expect the film to highlight the painter's 'action', and to frame this action as the primary cause of Pollock's work and the basis of what is most significant about it. But first we see (and hear) about the many other nominal causes of Pollock's work. The voice-over tells us where he was born and when, where he lives now, who he studied with, what kind of paint he likes. Then we see Pollock putting on his shoes, smoking a cigarette, kneeling to inspect the surface of a long stretch of canvas. He paces alongside it. After mixing some nearly dried paint in a can to restore its viscosity, Pollock begins painting rhythmically along the length of canvas, hunched to extend the reach of his arm over the horizontal plane. During the editing stage, Namuth interspersed close-ups of Pollock's hands and fingers, his furrowed brow in profile, and his balding head, with long-shots and pans of his measured lateral movement. Leading up to the action, Pollock stiffly delivers the film script in short sentences, his voice not quite synched with the cuts between one shot and the next:

My painting is direct.

I usually paint on the floor.

I enjoy working on a large canvas.

$[\ldots]$

Sometimes I use a brush, but often prefer using a stick.

Sometimes I pour the paint straight out of the can.

I like to use a dripping, fluid paint.

On the one hand, Namuth's visualization of the physicality of Pollock's technique and his immersion in his painterly activity accords with the artist's report - also voiced in the film - of feeling 'nearer' to a large canvas than a small one, of feeling that he is 'more a part of the painting', even 'in' it during its making. ${ }^{16}$ But on the other hand, the intensity conferred upon the action by Namuth's increasingly rapid cuts - a kind of cinematic action extended to 
Pollock's activity - combined with the awkward fit between Pollock's narration and Namuth's film shots, destroys the continuity Pollock elsewhere expressed of a 'pure harmony, an easy give and take' that he experienced when he was in 'contact' with his work. ${ }^{17}$ This awkwardness culminates in a film-noir scene in which we see the artist's stark shadow against a white wall, hunched over, holding a can, and repetitively flinging paint from a brush or stick that he swings down suddenly, as if it were a knife or other weapon instead of a painter's tool. $^{18}$

Even if Namuth's film, in its thematic exaggeration of Pollock's action, illuminates important aspects of the mechanics of the painter's technique, it obscures a viewer's interpretation of the artworks. Certainly, the director's handling of the artist's paintings undermines the way Pollock exhibited them. Viewers of the film, unlike those in a gallery, almost never see a work in its entirety. Accompanied by Morton Feldman's dissonant cello composition scored for the film, Namuth cuts from the shots of Pollock's shadow to extreme close-ups of some of his canvases, either held as still images, or panned by the camera in clockwise or counterclockwise movements. These partial shots are followed by Namuth's long pan of Summertime: Number $9 A$, I948, a painting that is well under a meter high but five and a half meters long. Yet instead of presenting this pan shot conventionally - so that it would yield for viewers a sense of camera movement from left to right along the painting's proper horizontal extent - Namuth orients the painting at a ninety-degree angle to the film's rectangular format, so that it appears to be moving from top to bottom with respect to the frame ('pulled slowly beneath the camera,' as he put it). ${ }^{19}$ Needless to say, this manipulation negates the particularity of Summertime to the degree that it is rendered nearly unrecognizable. When in the next shot we see a slow right-to-left pan of Pollock tacking the painting to a wall in the Betty Parsons Gallery, viewers are finally given the chance to see two paintings in their entirety, although they are forced to share the spotlight: Number 2, I950 (nearest to Lee Krasner, who is sitting to its right side) and Number 27, 1950. At this moment, Namuth suddenly cuts to a full-frame shot of just Number 27, 1950. But the painting is shown upside down. ${ }^{20}$ In sum, Namuth consistently denies Pollock's works their proper integrity by framing them in distorted aspects.

Namuth's account is causal in that it encourages viewers to identify Pollock's action as the meaning of his art. Barbara Rose noted the film's effectiveness in this regard. From the moment of its screening, she wrote:

the images of Pollock in action attached themselves as additional meanings to his works to a degree that they began to [affect] the perception of his paintings, which remained for most people [...] largely incomprehensible. ${ }^{21}$

Helpfully, Rose recognizes a distinction between what the paintings mean and what the film projects as their meaning. The film, as well as Namuth's photographs, 'provided an alternative to dealing with the difficulty of Pollock's painting'. In other words, Namuth substitutes a causal account for 
interpretation: the meaning of a painting, when reduced to action as cause, becomes manageable.

Yet a defect in the causal account quickly emerges. For in the film it is unclear what, exactly, might count as a cause of a work. It is basically true that Pollock's physical action causes the painting to appear in a certain way. But, then, are not other less obvious causes - the paint's viscosity, the earth's gravity, the direction of the wind as he paints outdoors - equally important? Is the fact that he puts on his shoes a cause, or is the fact that he smokes a cigarette one? In a gross sense, they all are. And Namuth's use of Pollock's statements multiplies the options. 'I was born in Cody, Wyoming', 'I spent two years [...] with Tom Benton', 'I [...] paint on the floor', 'I [...] prefer using a stick', 'I pour the paint straight out of the can': Namuth converts Pollock's statements into a causal litany. Whatever value they might have for interpretation outside the film's context, within the film they are not employed interpretatively. Assessing the film's numerous details, a viewer has no principle to leave anything out as a possible cause. Thus everything and anything might become part of the work's 'meaning'. Namuth's logic of causality culminates in the final portion of the film, where we see Pollock filmed through glass as he paints, exposing the invisible mechanics of Pollock's action. We get to look, as it were, under the hood of the car.

\section{The reduction of meaning to causes}

The obverse of radical inclusivity is Namuth's reduction of the meaning of Pollock's work to a single cause. In validating action above all other causes, Namuth converts Pollock's paintings into surfaces that index action: 'What is to go on the canvas [is] not a picture but an event,' in the critic Harold Rosenberg's words. ${ }^{22}$ Indexes operate by being directly linked to their cause (a fingerprint is an index of a fingertip), but not all indexes resemble their referents (while fingerprints resemble the surface areas of fingertips, smoke does not resemble fire). ${ }^{23}$ On the causal account, Pollock's marks obviously do not resemble what they are assumed to index, namely his physical actions. The pictorial meaning of 'action' is not an issue, since the marks that constitute Pollock's imagery are seen to be transcriptions of his action above and around the canvas, indexes of their literal cause; no interpretation necessary. My inclination is to take Namuth's emphasis on the putative indexicality of Pollock's marks to be an extreme version of the anti-intentionalist, causal position.

In an early assessment of Namuth's i $95^{\circ}$ photographs, taken before he made the film, the art historian Rosalind Krauss employs the concept of the index to draw out what she thinks is the significance of Namuth's pictures for our understanding of Pollock's paintings. In 'Reading Photographs as Text', Krauss polarizes two views of Pollock's work. In one view, the significance of the painter's practice resides in his process or technique. On this side stands not only Namuth, but also Rosenberg, whose essay 'The American Action Painters' of 
I 952 is often taken to apply to Pollock. Alternatively, Pollock's paintings can be seen as formally coherent works of art delivering an 'unmediated optical sensation' linked to an idea of what Krauss calls an 'immanence of meaning'. ${ }^{24} \mathrm{On}$ this side Krauss places Rosenberg's critical adversary, Clement Greenberg. But Namuth's images are relevant to interpreting Pollock's works, Krauss maintains, because they reveal the painter's 'attack on [this] idea of immediacy' and hence on self-evident meaning.

It is useful to focus on details of Krauss's argument in order to draw out other implications of Namuth's causal strategy. Krauss points out that photography and film enjoy a special relationship to the real, because they 'record' whatever is before the camera's lens as 'imprinted indexically' on its film, 'like a footprint in sand'. This indexical relationship, however, has consequences Krauss wants to avoid. Particularly, she wants to resist the 'fantasy of an unmediated relationship to the "real", that photographic indexicality encourages. This is a fantasy she thinks Greenberg's ideal of 'immediacy' promotes. Krauss asserts that Namuth's photographs attack immediacy by creating a 'rift' between the 'index' and the 'real'. She observes that Namuth's pictures, often taken from a high vantage point looking down on Pollock and his canvases, 'recapitulate that particular angle of vision which was the artist's own'. She then connects this high-angle view to nineteenth-century aerial photography. If we conventionally understand photography to index the real, then aerial photography mainly because it looks so unconventional - makes us question the assumption, and its imagery demands to be 'decoded'. It thus 'prick[s] the bubble of that fantasy' of the real to which we were uncritically accustomed. According to Krauss, this 'rupture' of our normal view of photography must necessarily be extended to our understanding of any photograph we later encounter. It puts us in the position, as the title of her essay reminds us, of always decoding, of always 'reading photographs as text'.

Analogously, Namuth's camera angle reveals a 'caesura' between the (horizontal) conditions under which Pollock marks his surfaces, and the (vertical) state of apprehending them as finished paintings. ${ }^{25}$ Once Namuth has revealed this rupture - like the rupture of the real inaugurated by decoding aerial photography - it must be carried into our viewing experience of all of Pollock's work. Pollock's paintings, Krauss seems to be saying, are like photographs in the sense that their indexicality brings them close to the 'real' (her scare quotes), but this should not tempt us to read them in terms of immediacy. Likewise, Namuth's photographs and film encourage us to include our knowledge of Pollock's causal process in our assessment of his finished works, so that we can no longer see his paintings as 'autonomous aesthetic objects' to be interpreted, but only as maps of action, or texts to be read. Their causes are now crucially linked to their meaning.

There are two damaging consequences of conflating meaning with causes. First, in making Pollock's surfaces into texts to be read, Krauss transforms his paintings into intentionless objects. Second, as intentionless objects, their 
'meaning' becomes dependent upon an empirical viewer's experience. The logic of these transformations starts with the idea that a text is comprised of signs that must be 'read', or made sense of in some way. But in Krauss's account, the signs of Pollock's text (the painting) are indexical. What they index is both the horizontal position of the canvas as it was being painted and, necessarily, the artist's action above it. ${ }^{26}$ Considered as indexes, Pollock's signs are thus converted into marks that transcribe their cause (again, 'like a footprint in sand'). The implication is that his work must be taken to consist entirely of its physical features, which reveals Krauss's commitment to the materiality of the signifier. In her post-structuralist view, signifiers are empty of meaning in themselves. They become meaningful only because of their difference from other signifiers and by virtue of their syntactical placement. So the meaning of Pollock's signifiers - his indexical marks - depends upon the beholder's judgements regarding competing possibilities of signification, which is to say that meaning becomes a matter of the viewer's experience. In reducing signs to indexes, Krauss transforms Pollock's paintings into just marked surfaces, objects to be encountered - not artworks to be interpreted.

The similarity of Namuth's framing of Pollock's practice to Krauss's poststructuralism might at first be difficult to see. It is hidden because Namuth emphasizes the apparent signifying potential of Pollock's technique. But as I have suggested, this emphasis on action, with its concomitant reduction of meaning to cause, makes the work of art an object of experience in the same way that the post-structuralist reduction of the work to a text does. It diverts attention away from the authorial meaning of works of art towards the beholder's response. If the process of making the work of art matters to its meaning, then the interpretation of the work of art will be based on an attempt - inevitably hopeless - to 'reconstruct' that process (the work's causes), and to attend to the responses it generates. Viewers will, for example, conflate the meaning of the artwork with the kinaesthetic reactions they have to the imagined movement of Pollock's arm as he spatters an arc of paint across a surface. Or they will equate the meaning of the artwork with their emotional response to it (an affective state they might imagine Pollock to have shared). In either case, 'meaning' is assumed to be a matter of a viewer's experience, and since no viewer will ever experience quite the same thing as another, meaning becomes contingent, variable and limitless. ${ }^{27}$

\section{The intentionalist position}

Identifying the singularity of the author's voice as a guarantee of its authenticity and originality has convincingly been criticized in post-structuralism. What has also been questioned is the very idea that artworks have a fixed meaning. ${ }^{28}$ In our contemporary interpretive context, the meaning of a text is equated not with the author's or artist's or maker's intention, but with the experiences of multiple readers. While the objection to the singularity of the authorial voice 
does nothing to diminish the claim that meaning and intention are the same thing - an intention complexly formed is still an intention - the commitment to the play of the text not only rejects the idea of fixed meaning, but denies the claim that intention is the condition for interpretation.

The consequences of rejecting intention as the condition for interpretation are illustrated by an example from Walter Benn Michaels and Steven Knapp's well-known essay, 'Against Theory'. ${ }^{29}$ Imagine that a person walking along a beach encounters a series of marks produced on the sand by a receding wave. Looking at them, the person realizes that the marks make letters, which spell out the words to a famous poetic line by Wordsworth. The question is, does what the person sees mean anything? Is it Wordsworth's poem he is reading? Michaels and Knapp argue that answers to these questions cannot be determined by giving an account of how the marks on the beach were made; the answers can only be given by asking whether or not the marks were intended to mean something. And since waves can't intend anything, the marks they leave on the beach cannot be meaningful (indeed, on what grounds would we know the marks are in English, although they look like they are, without recourse to intention?). Michaels summed up the problem generated by this example in a recent essay by saying that rejecting intentions

requires the transformation of all marks into the equivalent of [marks on a beach], intentional acts reconceived as natural events. Which is what makes the decision to treat them as any particular language, or as any language at all, arbitrary. And which thus turns what they are - because what they are is what they're treated as - into what they are for the reader. ${ }^{30}$

Disregarding intention turns the artwork into an intentionless object, and Michaels and Knapp's thought experiment is meant to demonstrate that something that does not have an intention cannot be interpreted. It would be absurd to 'interpret' what an object like a rock or a wave 'means': natural events, unlike intentional actions, require no interpretation. Since intentionless objects do not mean anything, the object will have significance only in terms of our experience of it. But describing our experience of something is not the same as interpreting a work of art.

There is a relevant historical reference point for some of these issues. During the period of Pollock's (and Namuth's) careers, the interpretation of literature was dominated by New Criticism, the most famous statement of which is the aforementioned I 946 essay by W. K. Wimsatt and Monroe Beardsley, 'The Intentional Fallacy' (and its companion piece, 'The Affective Fallacy'). ${ }^{31}$ Wimsatt and Beardsley argue for the public nature of literary language in an effort to establish an objective criticism of poetry, in opposition to approaches that conflate the meaning of a poem with the causal conditions - personal, social, biographical, political, cultural or economic - under which it was written. Such approaches, they argue, might tell us about what literally made or allowed it to come into existence, but tell us nothing about the meaning of a 
poem as a work of art. The critic's job is to interpret the meaning of poems, and to judge their success as works of art. Both tasks are independent of considering 'genetic' causes, conceived of as any material contingencies that may impinge upon a writer or artist:

There is a gross body of life, of sensory and mental experience, which lies behind and in some sense causes every poem, but can never be and need not be known in the verbal and hence intellectual composition which is the poem. ${ }^{32}$

As noted earlier, Wimsatt and Beardsley accuse those who conflate causal explanations with a poem's meaning of succumbing to an 'intentional fallacy'. The term is rather unfortunate, because they clearly do not oppose intention as I have been discussing it - indeed they are wholly committed to it. Rather, they are against using the limited idea of intention as the 'design or plan in an author's mind' as a criterion either for determining the correctness of interpretation or as a statement for making evaluative judgements. ${ }^{33}$ In a later essay, Wimsatt clearly distinguishes two opposed understandings of intention, claiming that the author's ultimately illusory 'generative intention' (intention as preformed mental plan that causes the work of art to come into existence) is a part of a whole 'cluster of genetically oriented ideas (inspiration, expression, authenticity, sincerity, purpose, and the like)' which attract 'simpler kinds of intention-hunters' but do not express 'a right view of literary "intention", ${ }^{34}$ In another context, the English critic F. R. Leavis expressed this 'right view' by writing:

[The critic] is concerned with the work in front of him as something that should contain within itself the reason why it is so and not otherwise. $[\ldots][1] \mathrm{t}$ is true that extraneous information may make him more percipient. But the business of critical intelligence [is] to ensure relevance of response and to determine what is actually there in the work of art [...]. Intentions are nothing in art except as realized, and the tests of realization [...] may very well reveal that the deep animating intention (if that is the right word) is something very different from the intention the author would declare. ${ }^{35}$

This 'deep animating intention' is precisely the meaning of the work of art. Anti-intentionalists substitute casual accounts for interpretation, thereby relinquishing claims about meaning.

\section{Interpreting Pollock}

Interpreting the meaning of artworks is identical to interpreting artistic intention. In a study of abstract painting, Charles Harrison has argued that it is precisely the ability of a viewer to interpret the artist's intentions as realized in the artwork that defines aesthetic sensitivity, and permits her to 'achiev[e] some sympathetic understanding of the conditions and concepts under which those intentions may have been formed'. ${ }^{36}$ But it is clear that Harrison is not talking about intention in a narrow sense, as a pre-formed mental plan. Approvingly, 
he cites Richard Wollheim's view that intention - which for Wollheim simply is the meaning of a work of art - can be conscious or unconscious. ${ }^{37}$ This flexible notion of intention as something partially known - in other words, partially unknown, even inscrutable - implies for Harrison that 'to assess the outcome of an intentional action (such as a work of art) it will therefore not be enough simply to ask what the artist meant'. ${ }^{38}$ The critic cannot rely on statements as avowals of the work's meaning; she must also see what the artist has done. Pollock, as I will show presently, would concur.

At the outset of this paper, I exploited the collaborative nature of Pollock's statements as a chance to problematize the issue of intention and meaning. I would like now to return to Pollock's statements in order to demonstrate their commensurability with the intentionalist position I have been advocating. For while those statements might not directly address what particular paintings mean, they do express the painter's views on intention. Pollock evidently thought intention was a combination of conscious and unconscious motives: 'When I am in my painting,' he said, 'I'm not aware of what I am doing. It is only after a sort of "get acquainted" period that I see what I have been about. ${ }^{39}$ Here, Pollock disputes the idea of intention as a mental plan. But elsewhere he insisted that he could 'control the flow of the paint'. ${ }^{40}$ He boldly declared, 'I deny the accident,' and shot off a telegram to Time magazine complaining 'NO CHAOS DAMN IT' after a critic disparaged the seeming indeterminacy of his work. ${ }^{41}$ Evidently the painter sensed no paradox in admitting unconscious intention yet denying chance: 'It doesn't make much difference how the paint is put on,' he remarked, 'as long as something has been said. Technique is just a means of arriving at a statement. ${ }^{42}$ How a work of art is made (consciously or unconsciously; with a stick or a brush; horizontally or vertically) is significant only insofar as it realizes an intention.

Arguably, what Pollock means when he insists that technique is a means of arriving at a statement finds a compelling parallel in Robert Pippin's recent analysis of Hegel's concept of agency. Pippin argues that Hegel rejected the division of an act into a prior and discrete interior intention that putatively causes an agent to act, and the exterior unfolding of the deed in a social context. Indeed, Hegel pried apart the notion of intention from what Pippin calls the 'uniquely firstpersonal and self-certifying intra-mental deliberative faculty' often assumed as foundational for an individual's sense of her own agency. ${ }^{43}$ Pippin's Hegelian view is that intention is not an originally determinate or privately owned mental content, but is rather revealed or detected in a deed that unfolds in a social world that precedes the agent. The individual 'arrives at' his intention (the content of his 'statement') after he acts. The agent learns his intention from the deed, one might say after a 'get acquainted' period. Pollock, like Hegel, challenges the causal model of agency in which actions are understood to result from an individual's originary, proprietary and executive powers. ${ }^{44}$

My point is that taking statements as evidence of what the artist 'meant' (as if some putative intra-mental event that 'causes' a work of art could be discovered) 
is a large part of the problem I have been discussing. Pollock, too, cautions us to ignore causes (techniques and means) and to focus our attention on the work of art (what has been expressed, the 'statement'). And this requires a sustained engagement with, and interpretation of, the perceptual effects Pollock intended to produce.

Admittedly, Pollock's paintings are often bewildering; hence the temptation to rely on statements by the painter as causal explanations, or on one's affective responses - in short, on anything that might help the viewer understand what at first seems incomprehensible. But an approach to Pollock's individual paintings which was analogous to the New Critics' approach to individual poems might be worthwhile pursuing. Only a rudimentary attempt can be made here, but let me adumbrate what such an approach might entail. Looking at Number I, I949 - one of the classic poured or dripped paintings Pollock made between I 948 and $195^{\circ}$ - it is difficult for a viewer to select from the surface any single pictorial incident that seems to impinge upon attention more than any other. Like the uniformly dispersed pictorial incidents, our eyes' focus and our mental attention are all-over, finding no place to rest and centred nowhere in particular. This thwarting of visual equilibrium has implications for how we interpret the modes of experience or consciousness Pollock wants to express. Yet once the gaze is suspended at the pulverized centre of the painting, another effect gradually occurs. It is not exactly that the centre of the painting becomes clarified, but that an elliptical area around the centre of the painting, about four feet across, appears as an area of relative stability, set off against a fringe of amorphous or unstructured activity that appears to surround it. The emergent structure given by this perceived ellipse slightly counters the all-over quality of the surface.

What are we to make of these perceptual effects? I propose that the effect of visual degradation in Number I, 1949 is achieved as if in opposition both to a sense of the perceived limits of the image (where it appears to end) and to a sense of the picture's physical edges, its frame (where it literally ends). Simply put, the surface's de-differentiation, its uniformity and lack of hierarchy, compromises the power of its external boundaries, perceived or literal, to establish pictorial structure. At the same time, though, the internal framing of the ovoid provides a certain emergent structure to the image which restores to the painting a degree of pictorial cohesiveness that is more or less independent of both its perceived limits and the literal frame, as if the pictorial structure is now understood to be generated from the inside out, from the interior of the image to its frame, rather than the other way around, and creates sense of the painting as a whole. I would suggest that the constitution of that totality - a structure that serves as a medium for expressive content, versus a merely literal shape is to be understood itself as emergent from the figurative depth of the field, not given beforehand. ${ }^{45}$ The total visual field then, far from being an accumulation of marks that are taken as traces or indexes of his movements or actions above the canvas, can be understood to be expressive of something like the subject's 
emergence to the world, and of the freedom of his or her creative intentionality. On this account, Number I, I949 conveys something about the conditions of experience through which a reflective subject might grasp the significance of her embodied modes of intentionality - her own deep animating intentions.

Anti-intentionalism, it is true, can motivate the historian to turn to other helpful explanatory frameworks outside the work, where useful analyses of the social, biographical, political or material contexts within which the work is embedded can be developed. However, as important as these contextual analyses can be, in them the task of interpreting the meaning of the work itself often yields to accounting for its causes. The work of art is treated as a result of certain pressures, an effect of its context's causing. I furthermore have tried to show that such accounts will terminate in the reduction of the artwork to a kind of intentionless object, the significance of which is determined only by our responses to it. Since objects do not have meaning in themselves, whatever significance they do have is what they have for us, and the task of interpreting the meaning of the work can lapse into describing our experience of the work's effects on us. But describing our experiences is not interpreting. Descriptions of experience, unlike claims about what the work means, are not open to question or argument. As I have suggested, Namuth's film is an extreme example of the causal position. The director conflates the meaning of Pollock's work with its causes; he is concerned neither with intention nor with interpretation. Let me repeat what Pollock himself said about the matter, a claim with which the intentionalist critic would be quick to concur: 'It doesn't make much difference how the paint is put on as long as something has been said. ${ }^{46}$ What gets said is exactly what the artist meant or intended, and it is the interpreter's task to try to understand what is being said, and among the things that are being said, to determine what about them is meaningful.

Department of Art E् Art History

Trinity University

San Antonio, Texas 78212

USA

mschreya@trinity.edu

\section{ACKNOWLEDGEMENTS}

The author gratefully thanks Linda Goddard and Natalie Adamson for their suggestions and encouragement, as well as Todd Cronan, Michael Fischer and Charles Palermo.

\section{NOTES}

1 Seldon Rodman, Conversations with Artists (New York: Capricorn Books, I 96 I), p. 8 I . 
2 Jackson Pollock, 'Interview with William Wright' [1950], reprinted in Fackson Pollock: Interviewes, Articles, and Revieres, ed. by P. Karmel (New York: Museum of Modern Art, I999), pp. $20-23$ (p. 23); hereafter cited as FP:IAR.

3 Steven Naifeh and Gregory White Smith, Jackson Pollock: An American Saga (New York: HarperPerennial, i989), pp. 663 and 89o. The film can be seen online at: <http://www.ubu.com/ film/namuth_pollock.html > [last accessed I5 March 20 I2].

4 For more on Pollock's susceptibility to what he calls Krasner's 'ventriloquism', see Carter Ratcliff, The Fate of a Gesture: Fackson Pollock and Postwar American Art (New York: Farrar, Straus, Giroux, I996), pp. 88-90.

5 Pollock, 'A Questionnaire' [1944], JP:IAR, p. I5. Ellen Landau notes that Peggy Guggenheim's secretary, Howard Putzel, helped Pollock formulate the answers to this questionnaire, itself the basis of his first full-length interview, and that Putzel 'constantly coached Jackson, literally rehearsing lines with him'. See Ellen Landau, Fackson Pollock (New York: Abrams, i 989), p. Io3.

6 Pollock, 'My Painting' [1947-48], JP:LAR, pp. I 7-18; and 'Interview with William Wright' [1950], , FP:IAR, pp. 20-23.

7 Pollock, 'Handwritten Statement' [no date], JP:IAR, p. 24; and Berton Roueché, 'Unframed Space' [1950], FP:IAR, p. I 8 . In the draft for the narration, Pollock also included material from his one other major public statement - an application for a Guggenheim Fellowship, written under the close guidance of Clement Greenberg - but ultimately chose not to use it. See Pollock, 'Application for Guggenheim Fellowship' [1947], FP:IAR, p. I 7. For a copy of the draft, see Ekkehard Putz, fackson Pollock: Theorie und Bild (Hildesheim and New York: Georg Olms Verlag, I975), pp. Io8-o9.

${ }^{8}$ Hans Namuth, 'Photographing Pollock', Pollock Painting, ed. by B. Rose (New York: Agrinde Publications, I978), n.p. Fred Orton and Griselda Pollock point out that this statement, dated I 7 November 1979 , is actually a version of two previously published texts from the I950s. See 'Jackson Pollock, Paintings, and the Myth of Photography', Avant-Gardes and Partisans Reviewed (Manchester and New York: Manchester University Press, I 996), p. I69, and p. i 76, n. 5. On the difficulties between Namuth and Pollock, see Naifeh and Smith, Jackson Pollock, pp. 65 I-53. Peggy Phelan sees the relation between Namuth and Pollock in terms of a kind of antagonistic collaboration in 'Shards of a History of Performance Art: Pollock and Namuth Through a Glass, Darkly', in A Companion to Narrative Theory, ed. by J. Phelan and P. Rabinowitz (Oxford: Blackwell, 2005), pp. 499-512. For an overview of the origins and development of films on art during this period, see Katerina Loukopoulou, 'Museum at Large: Aesthetic Education through Film', in Learning with the Lights Off: Educational Film in the United States, ed. by D. Orgeron, M. Orgeron and D. Streible (Oxford: Oxford University Press, 2012), pp. $35^{6-}-76$.

9 Orton and Pollock, Avant-Gardes and Partisans Reviewed, p. ii.

11 Paul Falkenberg, 'Notes on the Genesis of an Art Film', in Pollock Painting, n.p.

12 It is this conventional understanding of intention that Rosalind Krauss seems to hold when she writes: '[S]ince Pollock's statements can be shown to have been the result of a kind of ventriloquy practiced by his various mentors [...] they give us no reliable sense of his own intentions, but rather a script of self-justification to which he had recourse. I don't feel that Pollock's "intentions" are recoverable in any useful sense' (The Optical Unconscious [Cambridge, MA and London: MIT Press, I993], p. 322).

13 W. K. Wimsatt and Monroe C. Beardsley, 'The Intentional Fallacy' [1946], in W. K. Wimsatt, The Verbal Icon: Studies in the Meaning of Poetry (Lexington: University of Kentucky Press, 1954), pp. $3^{-1} 8$.

14 The classic statement of what I am calling a causal account is Harold Rosenberg, 'The American Action Painters', Art Neres (December 1952), 22-23 and 48-50. See also Allan Kaprow, 'The Legacy of Jackson Pollock', Art Newes (October 1 958), 24-27 and 55-57. Amelia Jones stresses what she terms the 'Pollockian performative' in Body Art/Performing the Subject (Minneapolis: University of Minnesota Press, I998), esp. pp. 53-57; Jonathan Katz sees the meaning of Pollock's works to lie in their index of the painter's body through 'gestural traces' in 'Jasper Johns and the Body Politic', in Performing the Body/Performing the Text, ed. by A. Jones and A. Stephenson (London and New York: Routledge, I999), pp. I 70-85 (p. I 80). Pepe Karmel productively uses Namuth's films and photographs to reconstruct Pollock's working process in his analysis, 'Pollock at Work: The 
Films and Photographs of Hans Namuth', in K. Varnedoe and P. Karmel, Fackson Pollock (New York: Museum of Modern Art, I999), pp. 87-137.

15 Karmel, 'Pollock at Work', p. 9i. Namuth made a shorter black and white film of Pollock a few months before the colour film I discuss here.

16 Pollock, 'My Painting' [1947-48], FP:IAR, pp. I 7- I8.

17 Ibid., p. I8.

18 Namuth admits that this scene was 'simulated' and considered removing it ('Photographing Pollock', n.p.); Karmel asserts that it is Namuth's own shadow ('Pollock at Work', p. I34, n. I 7).

19 Namuth, 'Photographing Pollock', n.p.

20 The only other paintings shown in their entirety during the film are the diminutive Number 17, I950 ('Fireworks') and Number 19, 1950, both two feet square paintings on board. Even Pollock's final painting on glass, Number 29, I950 - filmed from below while Pollock worked on it, and in some respects the star of the film - is shown cropped.

21 Barbara Rose, 'Hans Namuth's Photographs and the Jackson Pollock Myth, Part One', Arts Magazine, 53:7 (1979), I I 2- I6 (p. I I 2).

22 Rosenberg, 'The American Action Painters', p. 22.

23 See especially Charles S. Peirce, 'The Icon, Index, and Symbol', Collected Papers of Charles Sanders Peirce, ed. by C. Hartshorne and P. Weiss, 8 vols (Cambridge, MA: Harvard University Press, I93 I -58 ), Vol. 2 (I93 I), pp. I $34^{-} 73$.

24 Rosalind Krauss, 'Reading Photographs as Text', in Pollock Painting, n.p.

25 Krauss extends her analysis of the vertical and horizontal in relation to Pollock in The Optical Unconscious (Cambridge, MA: MIT Press, I993), pp. $24^{2}-320$.

26

27 On these points, see Walter Benn Michaels, The Shape of the Signifier (Princeton: Princeton University Press, 2004).

28 Classic statements of the anti-intentionalist position include Susan Sontag, 'Against Interpretation' [1964], in 'Against Interpretation' and Other Essays (New York: Delta, ig66), pp. 3-14; and Roland Barthes, 'The Death of the Author' [1968] and 'From Work to Text' [197 I], in Image Music - Text (New York: Hill and Wang, I977), pp. I $42^{2}-49$ and I $55^{-64}$.

29 S. Knapp and W. B. Michaels, 'Against Theory', Critical Inquiry, 8:4 (1982), 723-42.

30 W. B. Michaels, 'Neoliberal Aesthetics: Fried, Rancière and the Form of the Photograph', Nonsite, I: I (201 I), 5-6: <www.nonsite.org/issue-I > [last accessed 28 June 20 I 2].

31 W. K. Wimsatt and Monroe Beardsley, 'The Intentional Fallacy' [1946] and 'The Affective Fallacy' [1946], The Verbal Icon, pp. $3^{-18}$ and 20-39. See also Richard J. Calhoun, 'The New Criticism Ten Years After', Southern Atlantic Modern Language Association, 26:2 (1960), I-6; Murray Krieger, 'After the New Criticism', The Massachusetts Reviewe, 4:I (1962), I83-205; and René Wellek, 'The New Criticism: Pro and Contra', Critical Inquiry, 4:4 (I 978), 6 I I -24.

32 Wimsatt and Beardsley, 'The Intentional Fallacy', p. I 2.

33 For a careful consideration of this essay, see Jennifer Ashton, From Modernism to Postmodernism: American Poetry and Theory in the Twentieth Century (Cambridge: Cambridge University Press, 2005), esp. p. $18 \mathrm{I}$, n. 28.

34 W. K. Wimsatt, 'Genesis: A Fallacy Revisited', in The Discipline of Criticism: Essays in Literary Theory, Interpretation, and History, ed. by P. Demetz et al. (New Haven and London: Yale University Press, I 968), pp. $193^{-225}$ (pp. $19^{6-} 97$ and 22 I).

35 F. R. Leavis, 'Henry James and the Function of Criticism' [I948], The Common Pursuit (Harmondsworth: Penguin, I952), pp. 224-25.

36 Charles Harrison, 'Abstraction', in Charles Harrison et al., Primitivism, Cubism, Abstraction (New Haven and London: Yale University Press, I993), p. 262.

37 See also Richard Wollheim, Art and its Objects [1968] (Cambridge: Cambridge University Press, I980), pp. I $9^{-20 .}$ 
38 Harrison, 'Abstraction', p. 223.

39 Pollock, 'My Painting', 7 P:IAR, p. I 8.

40 Pollock, 'Interview with William Wright', JP:IAR, pp. 22-23.

41 Anonymous, 'Chaos, Damn It!', Time (20 November i95o), FP:IAR, p. 7o, and Pollock, 'Letter to the Editor, Time', 7 P:IAR, p. $7 \mathrm{I}$.

42 Pollock, 'Interview with William Wright', fP:IAR, p. 23.

43 Robert Pippin, Hegel's Practical Philosophy: Rational Agency as Ethical Life (Cambridge: Cambridge University Press, 2008), p. I 50. 44 Ibid., p. I 52.

45 Aspects of my analysis here follow Fried's lead in 'Shape as Form: Frank Stella's Irregular Polygons' [i 966], reprinted in Art and Objecthood: Essays and Reviewes (Chicago and London: University of Chicago Press, i 998), pp. 77-99.

46 Pollock, 'Interview with William Wright' [i 950], JP:LAR, p. 23; emphasis added. 